\title{
Adult bone-marrow stem cells and their potential in medicine
}

\author{
H T Hassan MD PhD M El-Sheemy MS PhD
}

J R Soc Med 2004;97:465-471

An area of research that today generates great optimism is the use of stem cells for therapy of human diseases. Much of the excitement centres on embryonic stem cells, but this approach remains controversial for ethical reasons; moreover, routine clinical application of this strategy is many years away. By contrast, haematopoietic stem cells from adult bone marrow are well characterized and have long been used therapeutically. ${ }^{1}$ An adult weighing $70 \mathrm{~kg}$ has a functional haematopoietic marrow volume of about $1.75 \mathrm{~L}$ and upon increased demands such as infection or haemorrhage it can increase sixfold., ${ }^{1,2}$ No moral controversy surrounds the use of these cells since they are either autologous or collected from a consenting donor. The potential applications of adult bone marrow cells have gained momentum with discoveries relating to the mesenchymal stem cell.

\section{MESENCHYMAL STEM CELLS}

Adult bone-marrow-derived mesenchymal stem cells (MSC) are capable of differentiation along several lineages (Box 1). ${ }^{3-15}$ They are positive for CD29, CD44, CD105 and CD166, have a doubling time of about two days, expand in culture up to sixfold and their biological functions are not altered by ageing.,15 Box 2 lists some of the cytokine receptors expressed by these cells and the cytokines produced. Their features and properties are closely similar to those of counterpart cells isolated from fetal blood, liver and bone in the first and second trimesters, from amniotic fluid and umbilical cord blood, and from adult peripheral blood, compact bone and adipose tissue. ${ }^{21-27}$ Moreover, a CD133-positive subpopulation of these cells, which can be expanded under defined conditions for more than one hundred population doublings without telomere shortening or karyotypic abnormality, has proved capable of differentiation not only into mesenchymal cell types (osteoblasts, chondrocytes, adipocytes, myocytes) but also into endothelium and cells with neuroectodermal phenotype and function. ${ }^{28-30}$ Previously, adult marrowderived stem cells were believed to yield a limited number

Institute of Medical Sciences, University of Lincoln, UK

Correspondence to: Professor H T Hassan, Director, Institute of Medical Sciences, University of Lincoln, Brayford Pool, Lincoln LN6 7TS, UK

E-mail: hhassan@lincoln.ac.uk
Box 1 Differentiation potential of adult bone marrow mesenchymal stem cells (from refs $3-15$ )

\begin{tabular}{ll}
\hline Adipocyte & Myofibroblast \\
Osteoblast & Endothelial cell \\
Chondrocyte & Neural cell \\
Cardiac myocyte & Hepatic cell \\
Skeletal myocyte & Renal tubular cell \\
Tenocyte &
\end{tabular}

of cell types whereas embryonic cells were totipotent. The discovery of these multipotent adult stem cells has clearly narrowed the gap: they offer a very promising and much more abundant potential resource for therapy of inherited or degenerative diseases and for repair of tissues such as cartilage, bone and myocardium.

\section{ADULT STEM CELL PLASTICITY}

What is the mechanism of stem cell differentiation? When the phenomenon was first explored, the possibility of cell fusion was mooted - that is, hybridization with other cells rather than true plasticity. Indeed, embryonic stem cells were seen to hybridize with brain cells to form tetraploid cells with pluripotent character. ${ }^{31}$ However, in-vitro and in-vivo studies of adult bone marrow stem cells suggest a

Box 2 Cytokine expression and production of human adult bone marrow mesenchymal stem cells (Refs $3,15-20$ )

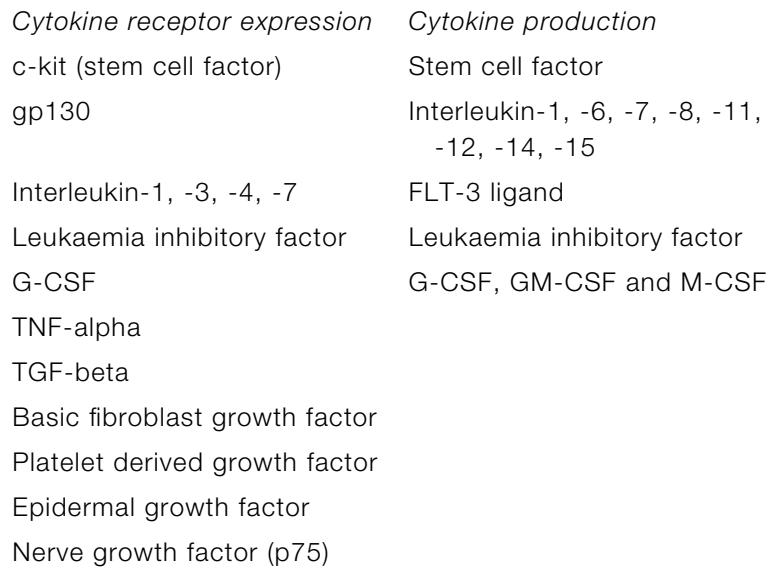

$\mathrm{G}-\mathrm{CSF}=$ granulocyte colony stimulating factor; $\mathrm{TNF}=$ tumour necrosis factor $\mathrm{TGF}=$ transforming growth factor; GM-CSF=granulocyte macrophage CSF; $\mathrm{FLT}=$ tyrosine kinase receptor 
rate of cell fusion too low to account for the transdifferentiation. ${ }^{32}$ Moreover, single euploid bone marrow MSC, never co-cultured with tissue-specific cells or embryonic cells, have been seen to differentiate into cells of the three germ layers; ${ }^{33}$ in vivo, the use of bone marrow cells selectively expressing the enhanced green fluorescent protein ruled out fusion as a mechanism for the generation of functional pancreatic islet beta cells; ${ }^{34}$ and hepatocytes, cardiomyocytes, and pancreatic and endothelial cells have been described as physiologically either diploid or polyploid. ${ }^{35-37}$ Certain cytokines, including interleukins (IL) 1, 4, and 13, tumour necrosis factor alpha and interferon gamma, are involved in the generation of normal multinucleated cells such as osteoclasts and Langhans giant cells ${ }^{38-40}$ thus, observations suggesting fusion of bone marrow cells with, for example, Purkinje neurons, cardiomyocytes and hepatocytes ${ }^{41}$ may instead simply reflect physiological polyploidy.

\section{BIOLOGY OF ADULT MARROW MESENCHYMAL STEM CELLS}

The direction in which bone marrow MSC differentiate is heavily influenced by cytokines (Table 1). For example, bone morphogenetic protein 6 (BMP-6) not only influences differentiation towards chondrogenesis or osteogenesis but may also serve to regulate the bone marrow environment via the effects of IL-6 on haematopoiesis and osteogenesis. ${ }^{50}$ Two possible mechanisms have been proposed for a regulatory role of BMP-6 in the human bone marrow microenvironment: (i) it might enhance the osteoblastic differentiation of human MSC; or (ii) it might reduce the osteoclastic differentiation of haematopoietic marrow cells by decreasing interleukin-6 production in bone marrow stroma. MSC coexpressing CD133 and fetal liver kinase 1 generated endothelial cells in the presence of vascular endothelial growth factor, and functional hepatocytes in the presence of fibroblast growth factor-4 and hepatocyte growth factor. ${ }^{29,30}$ Also, MSC coexpressing CD133, CD172 and nestin differentiated along a neural pathway in the presence of fibroblast growth factor or retinoic acid plus nerve growth factor. ${ }^{51,54}$ An MSC side-population with high efflux of DNA binding dye and expressing CD90 (Thy1) differentiated into mesangial renal cells. ${ }^{55}$

\section{MIGRATION/MOBILIZATION OF ADULT MARROW STEM CELLS}

In animal models, transplanted bone marrow cells have been detected in skeletal and cardiac muscle, ${ }^{56-58}$ vascular endothelium, ${ }^{58,59}$ liver, ${ }^{60-62}$ lung, gut and skin epithelia, ${ }^{62}$ pancreatic beta cell islets, ${ }^{34,63}$ renal glomeruli, ${ }^{14,55}$ and neural tissue. ${ }^{33,64-69}$ When bonemarrow-derived MSC were injected intracerebrally in acid-sphingomyelinase-deficient mice, the onset of neurological abnormalities was delayed and the animals lifespan was extended. ${ }^{70}$ Local transplantation of such cells is also reported to have regenerated bone $\mathrm{b}^{71-73}$ and myocardium. ${ }^{74,75}$ It is noteworthy that no donor-derived tumours have been seen in these animal models - whereas with transplantation of undifferentiated embryonic stem cells teratoma development has been reported. ${ }^{76}$ The results also differ from those of undifferentiated embryonic stem cell transplantation in that engraftment and tissuespecific differentiation are achieved without pretransplantation measures to induce differentiation down the lineage desired. The ability of marrow-derived cells to populate numerous body tissues - bone, liver, cardiac muscle, colon, skin - is well shown in patients who have received cells from gender-mismatched donors (Table 2). ${ }^{77-84}$ A postmortem study revealed donor-derived neurons in the hippocampus and cerebral cortex of brain samples from women who had received bone marrow transplants from men. ${ }^{85}$ Deductions from such findings must be qualified by the observation that women who have carried male fetuses may show long-term mosaicism with male cells;

Table 1 In-vitro differentiation conditions of human adult bone marrow mesenchymal stem cell

\begin{tabular}{lll}
\hline Tissue-type generated & Cytokines, reagents and conditions & Ref. \\
\hline Chondrogenic cells & TGF-beta and dexamethasone & 42 \\
& Bone morphogenetic protein-6 (BMP-6) & 43 \\
Prolactin & 44 \\
Osteogenic cells & Ascorbate, $\beta$-glycerophosphate and dexamethasone & 45,46 \\
Endothelial cells & Parathyroid hormone vitamin D3 \pm BMP-6 & 3 \\
Functional hepatocytes & Vascular endothelial growth factor & 29 \\
Neuronal cells & FGF-4 and hepatocyte growth factor on Matrigel & 30 \\
Mesangial renal cells & FGF and retinoic acid \pm NGF on fibronectin & $51-54$ \\
\end{tabular}


Table 2 Migration of human adult bone marrow stem cells in gendermismatched bone marrow transplantation patients

\begin{tabular}{lll}
\hline Donor male cells in female recipient & Frequency & Ref. \\
\hline Osteoblasts & $2 \%$ & 77 \\
Hepatocytes & $2 \%$ & 78 \\
Colon mucosal epithelial cells & $13 \%$ & 79 \\
Hepatocytes, gut and skin epithelia & $7 \%$ & $80^{\star}$ \\
Buccal epithelial cells & - & 81 \\
Purkinje cells & - & 82 \\
Myocardial cells & $10 \%$ & 83,84 \\
Cerebral (neural) cells & - & 85 \\
\hline
\end{tabular}

*Stem cells mobilized with granulocyte colony stimulating factor

nevertheless, the weight of the evidence is that donor bonemarrow-derived cells can migrate and give rise to tissues belonging to all three germ-cell layers. ${ }^{77-85}$ It is noteworthy that, in the transdifferentiation of these adult marrow stem cells, there was no evidence of cell fusion. ${ }^{77-85}$ Lately, work in mice indicated that such cells participate in skin regeneration and reconstitution and promote wound healing; ${ }^{86-88}$ and one research group reports a pilot study in three patients indicating that locally applied autologous bone marrow cells enhanced dermal building and closure of long-term non-healing wounds. ${ }^{89}$

\section{CLINICAL STUDIES}

In animal models of myocardial infarction, stem cells were reported to participate in repair whether injected locally or stimulated in bone marrow by use of stem cell factor (SCF) and G-CSF. ${ }^{90}$ In man, a randomized placebo-controlled study revealed increased coronary collateral flow in patients treated with intracoronary GM-CSF (molgramostim) followed by two weeks of subcutaneous administration. ${ }^{91}$

In the past decade the use of G-CSF (filgrastim) has transformed the treatment of cancer by facilitating marrow reconstitution after myeloablative therapy. We must hope for a similar breakthrough in the management of coronary heart disease.

In allogeneic transplantation, mesenchymal stem cells in bone marrow play a key part in immunomodulation and the induction of tolerance. MSC suppress the proliferation of T-lymphocytes induced by cellular or non-specific mitogenic stimuli ${ }^{92}$ and negatively influence B-cell lymphopoiesis. ${ }^{93}$ Allogeneic/xenogeneic MSC transplants engraft in immunocompetent sheep and non-human primates. ${ }^{94-97}$ When a patient was treated, after myeloablation, with both haematopoietic stem cells and cultured MSC from a mismatched donor, only grade I graft-versus-host disease (GvHD) was observed. ${ }^{98}$ That MSC can not only reduce GvHD but also facilitate haematopoietic engraftment is evidenced by the rapid haematopoietic recovery of patients with breast cancer who received autologous blood stem cells together with culture-expanded MSC after high-dose chemotherapy. ${ }^{99}$ In both clinical trials, MSC transplantation was well tolerated.

Osteogenesis imperfecta has been the focus of two studies in children. Allogeneic MSC transplantation, leading to successful osteoblast engraftment in 3 of 5 children with type III osteogenesis imperfecta, was associated with a $44-77 \%$ increase in bone mineral content, improved linear growth and reduced fracture frequency. ${ }^{77,100} \mathrm{In}$ another cohort of 6 children with type III osteogenesis imperfecta who had received earlier bone marrow transplantation, MSC infusions from the original donor resulted in a $50 \%$ improvement in their growth velocity. ${ }^{101}$ Similar improvements were observed in children with metachromatic leukodystrophy and Hurler's syndrome after repeated allogeneic marrow MSC infusions. ${ }^{102}$

Ten clinical studies have been reported on the effects of autologous bone marrow stem cell transplantation in patients with myocardial infarction or ischaemic heart failure (Table 3). ${ }^{103-112}$ In three pilot studies, two of them randomized controlled trials, bone marrow cells infused via a coronary catheter a few days after acute myocardial infarction led to significant improvement in coronary flow reserve and left ventricular ejection fraction. ${ }^{104,105,111}$ In the remaining seven, marrow cells injected directly into the myocardium of patients with chronic ischaemic heart disease yielded benefits in ejection fraction and also angina score. ${ }^{103,106-110,112}$

Despite the impressive safety record of all these pilot clinical trials, the possibility of undesired differentiation into other tissues must be borne in mind in monitoring of future studies.

\section{THE FUTURE}

In the next decade, the approaches discussed above will clearly be developed and refined. Further avenues will open up. For example, bone-marrow-derived cells expressing stem cell factor have been shown to initiate endogenous pancreatic tissue regeneration in mice. ${ }^{113}$ If such cells could be used as pancreatic beta islet cell progenitors, there would be scope for autologous transplantation in patients with diabetes, avoiding the need for the immunosuppression necessary after allotransplantation and circumventing the scarcity of allogeneic material. Whereas the multipotent adult dermal stem cells from human scalp skin have shown mainly neural differentiation, suggesting a possible therapeutic role in neurodegenerative diseases, ${ }^{114,115}$ the bone marrow MSC show strong orientation towards bone, cartilage, endothelium and cardiac muscle.

In conclusion, the existing medical uses of bone marrow are likely to expand greatly with exploitation of the 
No

Bone marrow (BM) cells Route of administration

Clinical outcome

Follow-up

(months) Ref.

Acute myocardial infarction

10

(5-9 days after injury)

20

(4 days after injury)

versus 11 control

30

(3-6 days after injury)

versus 30 control

Chronic ischaemic heart

disease

5

6

14

12

10

14

8
Mononuclear BM cell aspirate $2.1 \%$ CD34+, $0.6 \%$ CD133+ total 18 million CD34+ cells

Mononuclear BM cell aspirate $(n=9)$ 1-7 million CD34+ or blood progenitor cells $(n=11)$ 245 blood million cells

Mononuclear BM cell aspirate 4\% CD34+, total 3-15 million CD34+ cells

Mononuclear BM cell aspirate

Selected CD133+ BM cells; total 1.5 million CD133+ cells

Mononuclear BM cell aspirate

Selected CD133+ BM cells; With coronary artery total 1.5 million CD133+ bypass, 10 cells

Mononuclear BM cell aspirate

Mononuclear BM cell aspirate

Mononuclear BM cell aspirate

Intracoronary catheter 3
With coronary artery

bypass, 11

transendocardial injections of $0.1 \mathrm{~mL}$

With coronary artery

bypass, 10

transendocardial injections of $0.2 \mathrm{~mL}$

With coronary artery bypass

transendocardial injections of $0.2 \mathrm{~mL}$

Endomyocardial catheter injection

Endomyocardial catheter injection

Endomyocardial catheter injection

Intracoronary, 6-7 injections Increased contractility;

3

of $-3 \mathrm{~mL}$ containing 1.5-4 reduced hypokinetic

million CD34+ cells each

area

Increased global LVEF; reduced end-systolic; improved coronary flow reserve

Intracoronary, 4-5 injections Increased global LVEF;

6 of $5 \mathrm{~mL}$ each containing increased systolic wall 0.6-3 million CD34+ cells motion

Improved coronary

12

perfusion

Improved coronary

6

perfusion; improved

global LVEF

Improved global LVEF;

10

increased cardiac

function

Improved local perfusion; 12 improved global LVEF

Improved LVEF

3

Improved LVEF; reduced 2-4 end systolic volume

Increased wall motion $\quad 3$
106

104

LVEF=left ventricular ejection fraction

therapeutic potential of adult mesenchymal stem cells, with their capacity for many lines of differentiation. The next stage is to isolate the various subsets and investigate their mechanisms of differentiation and homing to tissues. This work has vast implications for human wellbeing, through cell and gene therapies, through tissue engineering and through immunotherapy.

\section{REFERENCES}

1 Hassan HT, Gutensohn K, Zander AR, Kuhnl P. CD34 positive cell sorting and enrichment: applications in bloodbanking and transplantation. In: Recktenwald D, Radbruch A, eds. Cell Separation: Methods and Applications. New York: Marcel Dekker, 1998:283-92
2 Hassan HT, Zander AR. Stem cell factor as a survival and growth factor in human normal and malignant hematopoiesis. Acta Haematol 1996;95:257-62

3 Sammons J, Ahmed N, El-Sheemy M, Hassan HT. The role of BMP6, IL-6 and BMP-4 in mesenchymal stem cells-dependent bone development; effects on osteoblastic differentiation induced by parathyroid hormone and vitamin $\mathrm{D}_{3}$. Stem Cells Devel 2004;13:273-80

4 Awad HA, Butler DL, Boivin GP, et al. Autologous mesenchymal stem cell-mediated repair of tendon. Tissue Eng 1999;5:267-77

5 Direkze NC, Forbes SJ, Brittan M, et al. Multiple organ engraftment by bone marrow-derived myelofibroblasts and fibroblasts in bone marrowtransplanted mice. Stem Cells 2003;21:514-19

6 Ryden M, Dicker A, Gotherstrom C, et al. Functional characterisation of human mesenchymal stem cell-derived adipocytes. Biochem Biophys Res Commun 2003;311:391-7 
7 MacKay AM, Beck SC, Murphy JM, Barry FP, Chichester CO, Pettenger MF. Chondrogenic differentiation of cultured human mesenchymal stem cells from marrow. Tissue Eng 1998;4:415-28

8 Wakitani S, Saito T, Caplan AI. Myogenic cells derived from rat bone marrow mesenchymal stem cells exposed to 5 -azacytidine. Muscle Nerve $1995 ; 18: 1417-26$

9 Sanchez-Ramos J, Song S, Cardozo-Pelaez F, et al. Adult bone marrow stromal cells differentiate into neural cells in vitro. Exp Neurol 2002;174:11-20

10 Schwartz RE, Reyes M, Koodie L, et al. Multipotent adult progenitor cell from bone marrow differentiate into functional hepatocyte-like cells. J Clin Invest 2002;109:1291-302

11 Reyes M, Dubek A, Jahagirdar B, Koodie L, Marker PH, Verfaille $\mathrm{CM}$. Origin of endothelial progenitors in human postnatal bone marrow. J Clin Invest 2002;109:337-46

12 Woodbury D, Schwartz EJ, Prockop DJ, Black IB. Adult rat and human bone marrow stromal cells differentiate into neurones. J Neurosci Res 2000;61:364-70

13 Imai E, Ito T. Can bone marrow differentiate into renal cells? Pediatr Nephrol 2002;17:790-4

14 Lin F, Cordes K, Li L, et al. Hematopoietic stem cells contribute to the regeneration of renal tubules after renal ischemia-reperfusion injury in mice. J Am Soc Nephrol 2003;14:1188-99

15 Suva D, Garavaglia G, Menetrey J, et al. Non-haematopoietic human bone marrow contains long-lasting pluripotential mesenchymal stem cells. J Cell Physiol 2004;198:110-18

16 Erices A, Conget P, Rojas C, Minguell JJ. Gp130 activation by soluble interleukin-6 receptor/interleukin-6 enhances osteoblastic differentiation of human bone marrow-derived mesenchymal stem cells. Exp Cell Res 2002;280:24-32

17 Caplan AI, Bruder SP. Mesenchymal stem cells: building blocks for molecular medicine in the 21st century. Trends Mol Med 2001;7:259-67

18 De Ugarte DA, Alfonso Z, Zuk PA, et al. Differential expression of stem cell mobilisation-associated molecules on multi-lineage cells from adipose tissue and bone marrow. Immunol Lett 2003;89:267-71

19 Roufosse CA, Direkze NC, Otto WR, Wright NA. Circulating mesenchymal stem cells. Int J Biochem Cell Biol 2004;36:585-97

20 Bonnet D. Biology of human bone marrow stem cells. Clin Exp Med 2003;3:140-9

21 Campagnoli C, Roberts IA, Kumar S, Bennett PR, Bellantuono T, Fisk NM. Identification of mesenchymal stem/progenitor cells in human first-trimester fetal blood, liver and bone marrow. Blood 2001;98:2396-402

22 Zvaifler NJ, Marinova-Mutafchieva L, Adams G, et al. Mesenchymal precursor cells in the blood of normal individuals. Arthritis Res 2000;2:477-88

23 Zuk PA, Zhu M, Ashjian P, Benhaim P, Henrick MH, Fraser JK. Human adipose tissue as source of multipotent stem cells. Mol Cell Biol 2002;13:4279-95

24 Romanov YA, Svintsitskaya VA, Smirnov VN. Searching for alternative sources of postnatal human mesenchymal stem cells: candidate MSClike cells from umbilical cord. Stem Cells 2003;21:105-10

25 Kuznetsov SA, Mankani MH, Gronthos S, Satomura K, Bianco P, Robey SA. Circulating skeletal stem cells. J Cell Biol 2001;153:1133-40

26 in't Anker PS, Noort WA, Scherjon SA, et al. Mesenchymal stem cells in human second trimester bone marrow, liver, lung and spleen exhibit a similar immunophenotype but a heterogeneous multilineage differential potential. Haematologica 2003;88:845-52

27 in't Anker PS, Scherjon SA, Kleijburg-van der Keur C, et al. Amniotic fluid as a novel source of mesenchymal stem cells for therapeutic transplantation. Blood 2003;102:1548-9

28 Reyes M, Lund T, Lenvik T, Aguiar D, Koodie L, Verfaillie CM. Purification and ex vivo expansion of postnatal human marrow mesodermal progenitor cells. Blood 2001;98:2615-25
29 Reyes M, Dubek A, Jahagirdar B, Koodie L, Marker PH, Verfaillie $\mathrm{CM}$. Origin of endothelial progenitors in human postnatal bone marrow. J Clin Invest 2002;109:337-46

30 Schwartz RE, Reyes M, Koodie L, et al. Multipotent adult progenitor cells from bone marrow differentiate into functional hepatocyte-like cells. J Clin Invest 2002;109:1291-302

31 Ying QY, Nicols J, Evans EP, Smith AG. Changing potency by spontaneous fusion. Nature 2002;416:545-8

32 O'Malley K, Scott EW. Stem cell fusion confusion. Exp Hematol 2004;32:131-4

33 Jiang $\mathrm{Y}$, Balkrishna N, Jahagirdar R, et al. Pluripotency of mesenchymal stem cells derived from adult marrow. Nature 2002;418:41-9

34 Janus A, Holz GG, Theise ND, Hussain MA. In vivo derivation of glucose-competent pancreatic endocrine cells from bone marrow without evidence of cell fusion. J Clin Invest 2003;111:843-50

35 Seglen PO. DNA ploidy and autophagic protein degradation as determinants of hepatocellular growth and survival. Cell Biol Toxicol 1997; 13:301-15

36 Brodsky V, Chernyaev AL, Vasilyeba IA. Variability of the cardiomyocytes ploidy in normal human hearts. Virchow Arch B Cell Pathol 1991;61:289-94

37 Lee GM, Rasch EM, Thornthwaite JT. Cytophotometric comparisons of DNA levels in neuronal and glial cells of the cerebellum: a comparative study. Cell Biochem Funct 1984;2:225-36

38 Anderson JM. Multi-nucleated giant cells. Curr Opin Hematol 2000;7:40-7

39 Merkel KD, Erdmann JM, McHugh KP, Abu-Amer Y, Ross FP, Teitelbaum SL. TNF-alpha mediates orthopaedic implant osteolysis. Am J Pathol 1999;154:203-10

40 Jimi E, Akiyama S, Tsurukai T, et al. Osteoclast differentiation factor acts as a multifunctional regulator in murine osteoclast differentiation and function. J Immunol 1999;163:434-42

41 Alvarez-Dolado M, Pardal R, Garcia-Verdugo JM, et al. Fusion of bone marrow-derived cells with purkinje neurones, cardiomyocytes and hepatocytes. Nature 2003;425:768-73

42 Yoo JU, Barthel TS, Nishimura K, Solchaga L, Caplan AI, Goldberg VM. The chondrogenic potential of human bone marrow-derived mesenchymal progenitor cells. J Bone Joint Surg 1998;80A:1745-67

43 Sekiya I, Colter DC, Prockop DJ. BMP-6 enhances chondrogenesis in a subpopulation of human marrow stromal cells. Biochem Biophys Res Comm 2001;284:411-18

44 Ogueta S, Munoz J, Obregon E, Delgado-Baeza E, Garcia-Ruiz JP. Prolactin is a component of the human synovial liquid and modulates the growth and chondrogenic differentiation of bone marrow derived mesenchymal stem cells. Mol Cell Endocrinol 2002;190:51-63

45 Coelho MJ, Fernandes MH. Human bone cell cultures in compatibility testing. Part II: effect of ascorbic acid, beta-glycerophosphate and dexamethasone on osteoblastic differentiation. Biomaterials 2000;21:1095-102

46 Jaiswal N, Haynesworth SE, Caplan AI, Bruder SP. Osteogenic differentiation of purified, culture-expanded human mesenchymal stem cells in vitro. J Cell Biochem 1997;64:295

47 Sammons J, Ahmed N, Khokher MA, Hassan HT. Mechanisms mediating the inhibitory effect of retinoic acid on haemopoietic stem cells in human long-term bone marrow cultures. Stem Cells 2000; 18:214-19

48 Ahmed N, Khokher MA, Hassan HT. Cytokine-induced expansion of human CD34 positive stem cell and CD34+CD41+ early megakaryocytic marrow cells cultured on normal osteoblasts. Stem Cells 1999;17:92-9

49 Ahmed N, Sammons J, Carson RJ, Khokher MA, Hassan HT. Effect of bone morphogenetic protein- 6 on haematopoietic stem cells and cytokine production in normal human bone marrow stroma. Cell Biol Int 2001;25:429-35 
50 Mbalaviele G, Jaiswal N, Meng A, Cheng L, Van Den Bos C, Thiede M. Human mesenchymal stem cells promote human osteoclast differentiation from CD34+ bone marrow hematopoietic progenitors. Endocrinology 1999;140:3736-3

51 Kim BJ, Seo JH, Bubien JK, Oh YS. Differentiation of adult bone marrow stem cells into neuroprogenitor in vitro. NeuroReport 2002;13:1185-8

52 Vogel W, Grunebach F, Messam CA, Kanz L, Brugger W, Buhring HJ. Heterogeneity among human bone marrow-derived mesenchymal stem cells and neural progenitor cells. Haematologica 2003;88:126-33

53 Sanchez-Ramos JR, Song S, Cardoz-Paleaz F, et al. Adult bone marrow stromal cells differentiate into neural cells in vitro. Exp Neurol 2000;164:247-56

54 Reyes M, Verfaillie CM. Characterisation of multipotent adult progenitor cells, a subpopulation of mesenchymal stem cells. Ann NY Acad Sci 2001;938:231-5

55 Ito $\mathrm{T}$, Suzuki A, Imai E, Okabe M, Hori M. Bone marrow is a reservoir of repopulating mesangial cells during glomerular remodelling. J Am Soc Nephrol 2001;12:2625-35

56 Ferrari G, Cusella-De Angelis G, Coletta M, Paolucci E, Stornaiuolo Cossu G, Mavilio F. Muscle regeneration by bone marrow-derived myogenic progenitors. Science 1998;279:528-30

57 Orlic D, Kajstura J, Chimenti S, et al. Bone marrow cells regenerate infarcted myocardium. Nature 2001;410:701-5

58 Jackson KA, Majka SM, Wang $\mathrm{H}$, et al. Regeneration of ischemic cardiac muscle and vascular endothelium by adult stem cells. J Clin Invest 2001;107:1395-402

59 Asahara $\mathrm{T}$, Takahashi $\mathrm{T}$, Masuda $\mathrm{H}$, et al. Bone marrow origin of endothelial progenitor cells responsible for postnatal vasculogenesis in physiological and pathological neo-vascularisation. Circulation Res 1999;85:221-8

60 Petersen BE, Bowen WC, Patrene KD, et al. Bone marrow as potential source of hepatic oval cells. Science 1999;284:1168-70

61 Theise ND, Nimmakayalu M, Gardner R, et al. Derivation of hepatocytes from bone marrow cells in mice after radiation-induced myeloablation. Hepatology 2000;31:235-40

62 Krause DS, Theise ND, Collector MI, et al. Multi-organ, multi-lineage engraftment by a single bone marrow-derived stem cell. Cell 2001;105:369-77

63 Lee VM, Stoffel M. Bone marrow: an extra-pancreatic hideout for the elusive pancreatic stem cell? J Clin Invest 2003;111:799-801

64 Brazelton TR, Rossi FMV, Keshet GI, Blau HE. From marrow to brain: expression of neuronal phenotypes in adult mice. Science 2000;290:1775-9

65 Kopen G, Prockop D, Phinney D. Marrow stromal cells migrate throughout forebrain and cerebellum, and they differentiate into astrocytes after injection into neonatal mouse brains. Proc Natl Acad Sci USA 1999;96:10711-16

66 Mezey E, Chandross KJ, Harta G, Maki RA, McKercher SR. Turning blood into brain: cells bearing neuronal antigens generated in vivo from bone marrow. Science 2000;290:1779-82

67 Priller J, Persons DA, Klett FF, Kempermann G, Kreutzberg SW, Dirnagl U. Neogenesis of cerebellar Purkinje neurons from genemarked bone marrow cells in vivo. J Cell Biol 2001;26:733-8

68 Azizi SA, Stokes D, Augelli BJ, Digirolamo C, Prockop DJ. Engraftment and migration of human bone marrow stromal cells implanted in the brains of albino rats - similarities to astrocyte grafts. Proc Natl Acad Sci USA 1998;95:3908-13

69 Schwarz EJ, Alexander GM, Prockop DJ, Azizi SA. Multi-potential marrow stromal cells transduced to produce L-DOPA: engraftment in a rat model of Parkinson's disease. Hum Gene Therapy 1999; 10:2539-49

70 Jin HK, Carter JE, Huntley GW, Schuchman EH. Intracerebral transplantation of mesenchymal stem cells into acid sphingomyelinase- deficient mice delays the onset of neurological abnormalities and extends their life span. J Clin Invest 2002;109:1183-91

71 Pereira RF, O'Hara MD, Laptev AV, et al. Marrow stromal cells as a source of progenitor cells for non-hematopoietic tissues in transgenic mice with a phenotype of osteogenesis imperfecta. Proc Natl Acad Sci USA 1998;95:1142-7

72 Niedzwiedzki T, Dabrowski Z, Miszta H, Pawlikowski M. Bone healing after bone marrow stromal cell transplantation to the bone defect. Biomaterials 1993;14:115-21

73 Kadiyala S, Jaiswal N, Bruder SP. Culture-expanded bone marrowderived mesenchymal stem cells regenerate a critical-sized bone defect. Tissue Eng 9197;3:173-85

74 Pak HN, Qayyum M, Kim D, et al. Mesenchymal stem cell injection induces cardiac nerve sprouting and increased tenascin expression in a Swine model of myocardial infarction. J Cardiovasc Electrophysiol 2003; 14:841-8

75 Shake JG, Gruber PJ, Baumgartner WA, et al. Mesenchymal stem cell implantation in a swine myocardial infarct model: engraftment and functional effects. Ann Thorac Surg 2002;73:1919-25

76 Thomson JA, Itskovitz-Eldor J, Shapiro SS, et al. Embryonic stem cell lines derived from human blastocysts. Science 1998;282:1145-7

77 Horwitz EM, Prockop DJ, Fitzpatrick LA, et al. Transplantability and therapeutic effects of bone marrow-derived mesenchymal stem cells in children with osteogenesis imperfecta. Nat Med 1999;5:309-13

78 Theise ND, Nimmakayalu M, Gardner R, et al. Liver from bone marrow in humans. Hepatology 2000;32:11

79 Okamoto R, Yajima T, Yamazaki $\mathrm{M}$, et al. Damaged epithelia regenerated by bone marrow-derived cells in the human gastrointestinal tract. Nat Med 2002;8:1011-17

80 Korbling M, Ktz RL, Khanna A, et al. Hepatocytes and epithelial cells of donor origin in recipients of peripheral blood stem cells. $N$ Eng J Med 2002;346:738-6

81 Tran SD, Pillemer SR, Dutra A, et al. Differentiation of human bone marrow-derived cells into buccal epithelial cells in vivo: a molecular analytical study. Lancet 2003;361:1084-8

82 Weimann JM, Charlton CA, Brazelton TR, Hackman RC, Blau HM. Contribution of transplanted bone marrow cells to Purkinje neurones in human adult brains. Proc Natl Acad Sci USA 2003;100:2088-93

83 Caplice NM, Bunch TJ, Stallboerger PG, et al. Smooth muscle cells in human coronary atherosclerosis can originate from cells administered at marrow transplantation. Proc Natl Acad Sci USA 2003;100,4754-9

84 Deb A, Wang S, Skelding KA, et al. Bone marrow derived cardiomyocytes are present in adult human heart: a study of gender mismatched bone marrow transplantation patients. Circulation 2003;107:1247-9

85 Mezey E, Key S, Vogelsang G, Szalayova I, Lange GD, Crain B. Transplanted bone marrow generates new neurons in human brains. Proc Natl Acad Sci USA 2003;100:1364-9

86 Kataoka K, Medina RJ, Kageyama T, et al. Participation of adult mouse bone marrow cells in reconstitution of skin. Am J Pathol 2003; 163:1227-31

87 Badiavas EV, Abedi M, Butmarc J, Flanga V, Quesenberry P. Participation of bone marrow derived cells in cutaneous wound healing. J Cell Physiol 2003;196:245-50

88 Stepanovic V, Awad O, Jiao C, Dunnwald M, Schatteman GC. Leprdb diabetic mouse bone marrow cells inhibit skin wound vascularisation but promote wound healing. Circulation Res 2003;92:1247-53

89 Badiavas EV, Falanga V. Treatment of chronic wounds with bone marrow-derived cells. Arch Dermatol 2003;139:510-16

90 Orlic D, Kajstura J, Chimenti S, et al. Mobilised bone marrow cells repair in infarcted heart, improving function and survival. Proc Natl Acad Sci USA 2001;98:10344-9

91 Seiler JG, Pohl T, Wustmann K, et al. Promotion of collateral growth by GM-CSF in patients with coronary artery disease: a 
randomised double blind placebo-controlled study. Circulation 2001; 104:2012-15

92 Di Nicola M, Carlo-Stella C, Magni M, et al. Human bone marrow stromal cells suppress T-lymphoctye proliferation induced by cellular or non-specific mitogenic stimuli. Blood 2002;99:3838-43

93 Shoham T, Parameswaran R, Shav-Tal Y, Brda-Saad M, Zipori D. The mesenchymal stroma negatively regulates $\mathrm{B}$ cell lymphopoiesis through the expression of Activin A. Ann N Y Acad Sci 2003;996:245-60

94 Bartholomew A, Sturgeon C, Siatskas M, et al. Mesenchymal stem cells suppress lymphocyte proliferation in vitro and prolong skin graft survival in vivo. Exp Hematol 2002;30:42-8

95 Liechty KW, MacKenzie TC, Shaaban AF, et al. Human mesenchymal stem cells engraft and demonstrate site-specific differentiation after in utero transplantation in sheep. Nat Med 2000;6:1282-6

96 Devine S, Bartholomew AM, Mahmud N, et al. Mesenchymal stem cells are capable of homing to the bone marrow of non-human primates following systemic infusion. Exp Hematol 2001;29:244-5

97 Devine S, Cobbs C, Jennings M, Bartholomew A, Hoffman R. Mesenchymal stem cells distribute to a wide range of tissues following systemic infusion in non-human primates. Blood 2003;101:2999-3001

98 Lee ST, Jang JH, Cheong JW, et al. Treatment of high-risk acute myelogenous leukaemia by myeloablative chemoradiotherapy followed by co-infusion of T-cell depleted haematopoietic stem cells and culture-expanded marrow mesenchymal stem cells from a related donor with one fully mismatched human leucocyte antigen haplotype. Br J Haematol 2002;118:1128-31

99 Koc ON, Gerson SL, Cooper BW, et al. Rapid haematopoietic recovery after co-infusion of autologous blood stem cells and culture-expanded marrow mesenchymal stem cells in advanced breast cancer patients receiving high dose chemotherapy. J Clin Oncol 2000;18:307-16

100 Horwitz EM, Prockop DJ, Gordon PL, et al. Clinical responses to bone marrow transplantation in children with severe osteogenesis imperfecta. Blood 2001;97:1227-31

101 Horwitz EM, Gordon PL, Koo WK, et al. Isolated allogeneic bone marrow-derived mesenchymal cells engraft and stimulate growth in children with osteogenesis imperfecta: implications for cell therapy of bone. Proc Natl Acad Sci USA 2002;99:8932-7

102 Koc ON, Day J, Nieder M, Gerson SL, Lazarus HM, Krivit W. Allogeneic mesenchymal stem cell infusion for treatment of metachromatic leukodystrophy (MLD) and Hurler syndrome. Bone Marrow Transplant 2002;30:215-22
103 Hamano K, Nishida $M$, Hirata $K$, et al. Local implantation of autologous bone marrow cells for therapeutic angiogenesis in patients with ischaemic heart disease: clinical trial and preliminary results. Jpn Circulation J 2001;65:845-7

104 Strauer BE, Brehm M, Zeus T, et al. Repair of infarcted myocardium by autologous intracoronary mononuclear bone marrow cell transplantation in humans. Circulation 2002;106:1913-18

105 Assmus B, Schachinger V, Teupe C, et al. Transplantation of progenitor cells and regeneration enhancement in acute myocardial infarction (TOPCARE-AMI). Circulation 2002;106:3009-17

106 Fuchs S, Satler LF, Komowski R, et al. Catheter-based autologous bone marrow myocardial injection in no-option patients with advanced coronary artery disease: a feasibility study. J Am Coll Cardiol 2003;41:1721-4

107 Perin EC, Dohmann HF, Borojlevic R, et al. Transendocardial, autologous bone marrow cell transplantation for severe, chronic ischemic heart failure. Circulation 2003;107:2294-302

108 Tse HF, Kwong YL, Chan JK, Lo G, Ho CL, Lau CP. Angiogenesis in ischaemic myocardium by intramyocardial autologous bone marrow mononuclear cell implantation. Lancet 2003;361:47-9

109 Stamm C, Westphal B, Kleine HD, et al. Autologous bone marrow stem-cell transplantation for myocardial regeneration. Lancet 2003;361:45-6

110 Galinanes M, Loubani M, Davies J, Chin D, Pasi J, Bell PR. Autotransplantation of unmanipulated bone marrow into scarred myocardium is safe and enhances cardiac function in humans. Cell Transplant 2004;13:7-13

111 Wollert KC, Meyer GP, Lotz J, et al. Intracoronary autologous bone marrow cell transfer after myocardial infarction: the BOOST randomised controlled clinical trial. Lancet 2004;364: $141-8$

112 Stamm C, Kleine HD, Westphal B, et al. CABG and bone marrow stem cell transplantation after myocardial infarction. $J$ Thorac Cardiovasc Surg 2004;52:152-8

113 Hess D, Li L, Martin M, et al. Bone marrow-derived stem cells initiate pancreatic regeneration. Nat Biotechnol 2003;21:763-70

114 Toma JG, Akhavan M, Fernandes KJL, et al. Isolation of multipotent adult stem cells from the dermis of mammalian skin. Nat Cell Biol 2001;3:778-84

115 Joannides A, Gaughwin P, Schwiening C, et al. Efficient generation of neural precursors from adult human skin: astrocytes promote neurogenesis from skin-derived stem cells. Lancet 2004; $364: 172-8$ 